DIVISION OF THE HUMANITIES AND SOCIAL SCIENCES

CALIFORNIA INSTITUTE OF TECHNOLOGY

PASADENA, CALIFORNIA 91125

ECONOMIC, POLITICAL, AND LEGAL FACTORS

IN FINANCIAL SYSTEM DEVELOPMENT:

INTERNATIONAL PATTERNS IN HISTORICAL PERSPECTIVE

Caroline M. Fohlin

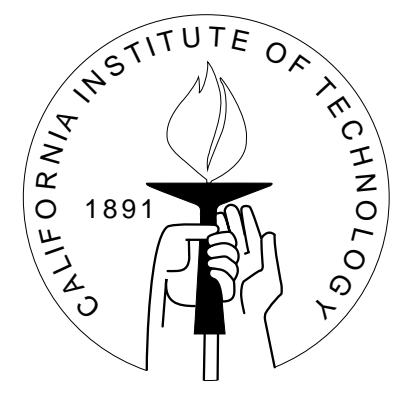

SOCIAL SCIENCE WORKING PAPER 1089

May 2000 


\title{
Economic, Political, and Legal Factors in Financial System Development: International Patterns in Historical Perspective
}

\author{
Caroline Fohlin* \\ California Institute of Technology
}

For presentation at the Midwest Political Science Association meetings, April 28, 2000, Chicago, IL. Draft: April 20, 2000

Preliminary

*I am grateful to several people who offered comments, advice, and expertise, particularly on the classification of banking and financial systems: Forrest Capie, Lance Davis, Steve Haber, Pierre-Cyrille Hautcouer, Annti Kuustera, Naomi Lamoreaux, Jaime Reis, Richard Sylla, Alan Taylor, Gail Triner, Hermann van der Wee, and Eugene White. 


\title{
Economic, Political, and Legal Factors in Financial System Development: International Patterns in Historical Perspective
}

\begin{abstract}
Financial systems are often described either as bank-based, universal, and relational or as marketbased, specialized, and arms-length; and for many years academics and policymakers have debated the relative merits of these different types of systems. This paper inquires into the underlying causes of financial system structure and development. Older theories dictated that financial institutions developed in relationship to the economy's level of development. Newer work has brought political and legal factors to the fore: hypothesizing specific relationships between banking structure and state centralization and between financial development and legal tradition. This study classifies countries by type of financial system, and in doing, indicates that few banking systems fit the extreme paradigms of universal-relationship or specialized-arms length banking. On the other hand, despite several cases of temporary upheaval, and recent widespread movement toward conglomeration, banking system structure has remained remarkable stable over the last 100 to 150 years.

Economic factors in the late nineteenth century provide relatively strong explanatory power for financial system development, market orientation, and banking structure at the eve of World War I and in the present day. Banking specialization and market orientation appear strongly associated with legal tradition, though it seems more likely that the three characteristics are jointly determined or that the legal system variable simply proxies for a close or historical tie to the exporter of many political-economic institutions, England. Legal orientation exerted little impact on financial institution growth at the turn of the century and provides no consistent prediction of real economic growth rates over the past 150 years. Finally, political structure relates significantly to market orientation but not to banking system design or legal tradition. Nonetheless, many individual country histories make it clear that political forces played important roles in shaping regulations that in turn altered the course of financial institutions and markets. The results here simply suggest that these political forces appeared inconsistently and had no traceable, uniform relationship to the overall political system in place in the nineteenth century.

The results underscore two principal themes: the weight of history in determining the growth and design of financial institutions and markets, and the importance of idiosyncratic forces that buffet institutions over time. Despite obvious connections among political, legal, economic, and financial institutions, robust, long-term, causal relationships often prove to be elusive.
\end{abstract}




\section{Economic, Political, and Legal Factors in Financial System Development: International Patterns in Historical Perspective}

Financial systems are often described in binary terms: bank-based or market-based, universal or specialized, or relational or arms-length. For the past century, economists have taken strong positions on the relative strengths and weaknesses of different systems, and a bit of a horse-race has ensued. While many have investigated the impact of financial development on economic growth, a smaller literature has begun to inquire into the underlying causes of financial system structure and growth. Older theories dictated that banks had to develop faster, and needed to provide more services, in countries that were undergoing rapid industrialization during the end of the nineteenth century. The most and least developed economies of the time, respectively, did not need or could not support such large-scale, industrial banks. Newer work has brought political and legal factors to the fore: hypothesizing specific relationships between banking structure and state centralization and between financial development and legal tradition.

The natural starting point of this study is a classification of countries by type of financial system. Such a sorting exercise begins the paper and indicates that few banking systems fit the extreme paradigms of universal-relationship or specialized-arms length banking; the vast majority fall somewhere in between. In addition, though connections do emerge among design of banking institutions, engagement in formal relationships, and prevalence of stock markets, there are few hard and fast rules. In general, empirically, institutions and systems are very difficult to categorize crisply. Despite several cases of temporary upheaval, and recent widespread movement toward conglomeration, banking system structure has remained remarkable stable over the long run-that is, over the last 100 to 150 years.

The second stage of the analysis seeks to identify the political and economic characteristics that unify countries under a given financial paradigm. This exercise reveals a number of consistent patterns. For example, economic factors in the late nineteenth century provide relatively strong explanatory power for financial system development, market orientation, and banking structure at the eve of World War I and in the present day. Banking specialization and market orientation appear strongly associated with legal tradition, though it seems more likely that the three characteristics are jointly determined or that the legal system variable simply proxies for a close or historical tie to the exporter of many political-economic institutions, England. Finally, political structure relates significantly to market orientation but not to banking system design or legal tradition. 
These findings lead to two sets of conclusions. First, modern financial systems are rooted in the past and are highly path-dependent: many financial systems-particularly those in highly-developed, western economies-took shape in the pre-World War I period. Therefore, to understand the current structure of financial institutions, we must take stock of the political and economic forces at play in both the near and distant past: that is, the 1850 s as well as the 1950s. Second, many influences converge to mold financial institutions over time. Political and regulatory intervention, though influential on system design, is idiosyncratic to specific countries. Thus, though social and political contexts play important roles in shaping institutions, it is difficult to pinpoint reliable relationships among economic, political, legal, and financial variables.

\section{Existing Research on Financial System Development}

The fundamental characteristic of universal banking is the joint provision of a wide range of financial services by the same institution: true universal banks are allowed to provide virtually any product. These supermarkets of corporate finance typically combine standard commercial banking functions (short-term credit, deposit taking, payments clearing, bill discounting) with underwriting and trading in securities. Modern universal banks also sell insurance, mortgages, and investment funds, though they usually do so through affiliates. Universal banking emerged in many countries, but the German incarnation has come virtually to define this institutional form. American banks (since Glass-Steagall) and British (until the end of the twentieth century) provide the classic counterexamples to the universal system.

It is useful to delineate a second set of bank characteristics, relationship banking, that is often (erroneously) considered part of universal banking. Primary examples include holding equity stakes, voting shares in proxy for customers, and sitting on the boards of directors or supervisory boards of client firms. Not all universal banks perform the complete range of relationship banking functions, and not all financial institutions that provide some of these functions are universal banks.

Branching over extensive geographic areas is also often identified with universal banking but is really a separate issue. While the practicality of universal banking may hinge on size, branching is not necessary. Indeed, the first universal banks were unit banks, and those in Germany operated as such for decades before beginning to branch. Moreover, since a primary benefit of geographic dispersion is diversification potential, branching may be equally beneficial to specialized banks, such as those in Britain. 


\section{Theory and Evidence}

There is a large and multi-faceted literature on the relationship between financial and real development. While most economists recognize that the financial system is a crucial component of any economy, there is much disagreement over the manner in which financial and real variables interact. There is far less work on the causes or consequences of financial system design, and, in particular, little theoretical work available to guide an investigation into the determinants of financial system design.

Expansion of the financial sector has proven to go hand in hand with economic growth, but the direction of causality is still uncertain. ${ }^{1}$ Joan Robinson (1952) suggested that financial systems develop in response to prospects in the real sector, yet the literature over the last decade has tended to argue that the real sector responds to financial development. The evidence seems to support the view that the extent and depth of the financial system positively correlates with future economic growth, but problems of omitted variables and robustness undermine such findings.

The idea that financial institutions can actively promote growth is quite old. Joseph Schumpeter (1912) argued that bankers, through their screening and funding of entrepreneurs, encourage innovative activity and thereby spur economic growth. Thus, the early writing on the financial system took as a given both the asymmetry of information between investors and entrepreneurs and the role of the financial system in ameliorating such information problems. Modern growth theory stresses the acquisition of human capital and the productivity of economic units (firms and entrepreneurs) as well as the traditionally-emphasized expansion of the physical capital stock. This literature has also made strides in incorporating the financial system into models of endogenous growth.

The recent work of Robert King and Ross Levine (1993), for example, formalizes the Schumpeterian view into the framework of an endogenous growth model. In their model, the financial system affects productivity growth through four channels: screening prospective entrepreneurs in order to select the most promising projects, mobilizing capital to fund investments, diversifying investors' portfolios to eliminate risk, and revealing the potential benefits of participating in productivity-enhancing activities. ${ }^{2}$ Thakor (1996), who

\footnotetext{
${ }^{1}$ Early studies include Gurley and Shaw (1955), Goldsmith (1969), McKinnon (1973), and Shaw (1973).
}

${ }^{2}$ The more recent literature considering the causal relationship between finance and growth includes King and Levine (1993), Tullio Jappelli and Marco Pagano (1994), Jith Jayaratne and Philip Strahan (1996), and Rajan and Zingales (1997). Robert Lucas (1988), perhaps not surprisingly, expresses doubt about the importance of financial factors and excludes these considerations in his model of development. Marco Pagano (1993) and Alexander Galetovic (1996) provide good reviews of the newer growth literature. 
is explicitly concerned with the question of financial system design, lays out six partially-overlapping links between the financial system and the real economy: screening by banks, credit rationing by banks, liquidity transformation and bank runs, loan commitments by banks, debt restructuring, and the feedback role of financial markets. In general, financial institutions may enhance economic growth by raising the total quantity of financial capital available to entrepreneurs, improving the quality (productivity) of investments, and increasing the efficiency of intermediation between the sources and uses of funds.

The question of causality remains a problem in the theoretical literature, though recent work is beginning to offer models in which influences run in both directions. Greenwood and Smith (1997) and Boyd and Smith (1996) offer a reasonable compromise: models in which financial markets arise after some period of real development, and the expansion of those markets fuels further real growth. A logical implication of these models is that exogenous creation of a financial system with advanced features may not spur real growth.

These latter two models also begin to deal with the real ramifications of financial system structure, particularly the varied impact of banks and securities markets. Though most of the literature offers no comparison of the relative benefits of different types of financial systems, the Greenwood and Smith (1997) model shows that, with sufficient risk aversion on the part of the investing public, equity markets produce stronger growth than do banks. In a series of papers, Boyd and Smith $(1994 a, 1995,1996)$ introduce the changing roles of debt and equity in the development process and show that, though stock markets should develop after a period of intermediary dominance, both debt and equity remain viable and complementary sources of finance. Moreover, Greenwood and Smith (1997) show theoretically that growth rates obtained in economies with either banks or equity markets exceed those of economies without financial intermediaries.

Another line of research suggests that there are tradeoffs between banks and financial markets in the revelation and transmission of information necessary for making optimal real decisions; the desirability of one system over another depends on the context. Allen (1992) reasons that, because markets aggregate information from a wide range of disparate sources, but banks depend primarily on their own assessments, markets dominate banks when technologies are new, complex, or rapidly evolving. Banks prevail when technologies are clearly understandable and optimal investment decisions are easy to make. Also, as Thakor (1996) argues, bank-dominated systems exacerbate effort-aversion and overinvestment, while market-based systems lead to excessive reliance on borrower reputation as well as greater asset-substitution moral hazard. ${ }^{3}$ Furthermore, the analyses of von Thadden (1990) and Dewatripont and Maskin (1990) suggest that banks tend to prolong low-quality projects for too long, while markets often liquidate good projects prematurely. All of these

\footnotetext{
${ }^{3}$ Thakor bases his argument on the predictions of Rajan (1992), Wilson (1994), and Diamond (1991).
} 
problems can lead to sub-optimal investment decisions and lower real economic growth.

The structure of financial intermediaries, particularly commercial banks, may influence real variables, since different institutions may handle their tasks with varying degrees of efficiency. The existing literature, however, focuses on the difference between banks and stock markets in the allocation of investment capital and not on the real effects of various types of banking institutions. ${ }^{4}$ Theoretical differences in growth effects may be inferred from some other recent work. Relative to specialized, arms-length systems, for example, universal and relationship banking may be better suited to perform the growth-enhancing functions described by King and Levine (1993) or Thakor (1996). ${ }^{5}$ Nonetheless, while it is clear that financial systems vary in their real effects, it is not yet clear what kind of system offers the greatest net benefit to the real economy-either historically or at present. Perhaps tellingly, the latest work by Levine (2000) finds no statistical relationship between the emphasis on banks relative to markets and real economic growth in the 1990s.

The existing literature combines a number of different approaches to the issue of financial system design. Many older studies, as exemplified by Gerschenkron's work, treat universal banks as a second-best substitute for missing markets. Recent research on modern institutions, on the other hand, conceives of the debate as a battle of competing systems arrayed on an even playing field. The results to follow indicate that several countries maintained at least partially specialized, arms-length systems even in the absence of prohibitions on universal or relationship banking: British commercial banks, for example, have always been permitted to engage in universal and relationship banking, but have apparently mostly refrained. Until very recently, the 'battle of the systems' literature has represented universal, relationship banking as a superior solution to asymmetric information problems, and therefore this literature would interpret the British and American resistence to universality as, respectively, entrepreneurial and regulatory failure. The 'substitute for markets' literature would see this persistence of specialization as a sign and natural upshot of the continued availability of the preferred market institutions. This divergence in perspectives is worth keeping in mind in analyzing the differences in financial system design and its determinants.

\footnotetext{
${ }^{4}$ This conflation of banking structure both with corporate governance issues and with financial market activity results from the perception that universal, relationship-based banks dominate the financial systems in which they operate, and that financial markets dominate in systems in which financial intermediaries are specialized. See Helmut Dietl (1998) and Jonathan Story and Ingo Walter (1997).

${ }^{5}$ Tellingly, the latest work by Levine (2000) finds no statistical relationship between the emphasis on banks relative to markets and real economic growth in the 1990s.
} 


\section{Determinants of Financial System Design}

Although most of the literature addresses the impact of financial system organization and growth, a smaller line of research investigates the underlying impetuses for financial development and structure. Gerschenkron offered probably the best-known general hypothesis about the genesis of financial institutions. ${ }^{6}$ In essence, he argued that banks played a more important role in industrialization for 'moderately backward' economies than they had played for the earliest industrializer, Great Britain. According to his schema, financial institutions played a critical role in the industrialization of much of northwestern continental Europe. In situations of extreme underdevelopment, as in Russia, financial institutions were insufficient to support the transition to modernized industrial activity; such cases demanded centralized institutional intervention, mostly from government.

More specifically, Gerschenkron argued that, because of their ability to adopt technologies from industrialized areas, relatively 'backward' economies modernized faster than their role models. The scale of factories and firms required to compete, however, was so large as to prohibit self-financing. Follower economies therefore needed institutions capable of mobilizing a high volume of capital from disparate sources and also able to compensate for a shortage of entrepreneurship. In Gerschenkron's view, the German universal banks were just such an institution:

"The German investment banks---a powerful invention, comparable in economic effect to that of the steam engine---were in their capital-supplying functions a substitute for the insufficiency of the previously created wealth willingly placed at the disposal of entrepreneurs."7

Nested within this traditional paradigm (and the Gerschenkron Hypothesis) is the idea that lack of economic development necessitated special characteristics and growth-promoting practices of banks: mobilizing capital through large networks of branches, screening potential entrepreneurs, providing long-term lending, deciding on investment and production strategies, monitoring the progress of clients' investments, promoting and re-organizing industries, arranging and enforcing industrial combinations, and diversifying away the inherent

${ }^{6}$ Gerschenkron $(1962,1968,1970)$. Sylla (1991) reviews Gerschenkron's theories and related work. Knick Harley (1991) addresses Gerschenkron's idea of ‘substitution for prerequisites’ of industrialization.

${ }^{7}$ Gerschenkron (1968), p. 137. Gerschenkron (1970, p. 98-9) saw banking as only one of many factors (such as industrial growth rates, plant scale, emphasis on heavy industry, passivity of agriculture, technological importation, and ideological virulence) that varied with the extent of economic 'backwardness.' Less clear is the causal connection. 
risk. Along similar lines, Allen (1992) and Allen and Gale (2000) argue, in part, that the historical experiences of Britain and the U.S. support the idea that markets are preferable in situations of complex decision processes and rapidly-advancing technology; whereas banks should dominate where optimal investments are agreed upon and primarily just need monitoring. ${ }^{8}$

Gerschenkron's work remains influential in modern thinking about financial system design, but recent work has also questioned his heavy emphasis on economic factors in determining the shape and role of financial institutions. Economic backwardness may be a proximal cause of rapid financial development during industrialization; but other factors are likely to have constrained real development and financial development up to the point of industrialization. Some have argued that the Gerschenkronian view under-emphasizes the role of political and legal factors in the development of financial systems. The Bubble Act of 1720 and the monopoly of the Bank of England over limited liability banking until 1825, for example, kept the British banks excessively small and conservative. Moreover, the lack of dependable lender of last resort facilities reenforced the reluctance of bankers to engage in risky transformation of short-term liabilities to potentially illiquid assets (Ziegler, 1993, Kennedy, 1992, and Tilly, 1994). The standard view holds that the German Reichsbank, in contrast, both squeezed other banks out of much of the short-term commercial business and facilitated those banks' provision of riskier investment services. Forrest Capie (1999), however, argues that the lender of last resort function became dependable in continental Europe only after the turn of the twentieth century. Thus, there is still some debate over the timing, and therefore potential influence on industrialization, of central banking activities.

Much of the variation in financial system structure may result from peculiarities of financial system regulation. Government intervention may hamper all development or might promote certain institutions at the cost of others. Some have argued, for example, that government regulation in Germany simultaneously promoted the large, universal banks and hampered operation of securities markets. Similarly, limitations on bank operations may have spurred financial market development in the U.S., especially during the twentieth century. Regulation of non-bank institutions-such as securities markets, corporate chartering, limited liability, and bankruptcy-may have further altered the shape of financial systems. For example, laws that protect investors, contracts, and property rights might be argued to encourage the development of all kinds of financial institutions, and particularly atomistic market arrangements. ${ }^{9}$

The enactment of laws is not exogenous; the process depends on both the legal and political conditions.

\footnotetext{
${ }^{8}$ Boot and Thakor (1997) and Thakor (1996) address the question of financial system structure and innovation.

${ }^{9}$ On Germany, see the edited volume by Horn and Kocka (1979) especially those by Horn, Friedrich, and Reich.
} 
Certain legal systems produce more enabling legislation than do others. In a series of recent papers, LaPorta, et al $(1997,1998,1999)$ have argued for the importance of legal traditions in determining the development of financial markets. In particular, based on modern evidence, they find that countries adhering to a French civil law system have both the weakest investor protection, through both legal rules and law enforcement, and the least developed capital markets. Common Law countries fall at the other end of the spectrum. American and British economies or societies has led to market-oriented financial systems. Similarly, Dietl (1998) lays out the poles, admittedly highly stylized, of neoclassical versus relational regulation. These extremes map directly to common law and civil law legal systems, respectively. In Dietl's schema, neoclassical systems focus on allocative efficiency with the objective of eliminating capital market imperfections. This legal environment leads to strictly enforced accounting regulations and effective prohibitions on insider trading, market manipulations, anti-competitive behavior, and on true universal-relationship banking. Relational systems focus on coordinative efficiency with the goal of enhancing corporate governance and reducing the costs of financial distress. The results, in the extreme, contrast starkly with the neoclassical system: weak or vague laws on accounting, insider trading, market manipulations, anti-competitive behavior, and banking scope. Connecting the arguments of LaPorta, et al and Dietl, results in the hypothesis that neoclassical, or common law, legalregulatory systems encourage market-based financing with specialized banking and a short-term investment perspective; relational, or civil law, systems yield the counterpart.

Rajan and Zingales (1999) have also recently contributed to the debate over determinants of overall financial system development and specifically contrast legal and political influences. Directed primarily at the LaPorta, et al series, Rajan and Zingales point out that, except for the outlier, Britain, the most developed countries in 1913 maintained similar levels of financial development, regardless of legal system. These authors argue that not legal systems, but political contexts-the support of financial institution growth by government and interest groups-determine the course of development. Landed gentry, for example, typically oppose financial development, while industrial bourgeoisie champion the cause. The government itself may also harbor incentives for or against financial development. Examples such as the 1848 bourgeoisie revolutions in continental Europe (promoting financial development) and the dictates of the Japanese government in the 1930s (impeding financial development) bolster this impressionistic account of financial and political history. As the discussion reveals, characteristics of political systems, such as centralization of power or strength of interest groups, may at least partly depend on legal tradition: common law aids devolution of power to the periphery, while civil law more likely thwarts it. Yet the authors note that civil law can, if motivated, replicate the common law outcome; thus implicitly raising the question of underlying motivations for legal systems. The 
authors' discussion can be read as equating financial development with the expansion of financial markets. From this idea, one could perhaps infer, in the spirit of Gerschenkron, that hierarchical forms of financial institutions, such as banks, evidence lack of financial development. Thus, whereas Dietl's dichotomy places neoclassical (common law, market-based, specialized-arms-length banking) systems on an equal footing with relational (civil law, hierarchy-based, universal-relationship banking) systems, Rajan and Zingales' hypothesis (ala Gerschenkron) suggest an unequal ordering.

Verdier (1997 and 1999) hits on similar themes, but lays out a political-economic view of the development of financial systems. In doing so, he takes direct aim at Gerschenkron's hypothesis about the relationship between the extent of economic backwardness and the role of financial institutions. He argues that political structure, not relative backwardness, determines the shape of financial systems. In particular, universal banking arose in the coincident presence of two conditions: first, a segmented deposit market, dominated by non-profit and provincial banks and, second, a reliable lender of last resort facility insuring liquidity in the banking system. Furthermore, he argues, these two preconditions for universality emerged simultaneously only when state centralization was sufficient to provide a strong central bank (with credible LOLR status) but limited enough to permit coexistence of provincial and, in his parlance, 'center' banks. The issue of legal system does not appear in Verdier's analysis, but the other work reviewed here suggests a possible connection. As Verdier concedes, however, political centralization was neither solitary nor decisive in determining financial structure in most cases. Thus, whether Verdier correctly characterizes the relationship between political and financial development, he does not clearly subvert Gerschenkron's hypothesis.

So far, neither formal theoretical research nor cogent empirical research has rationalized the endogenous development of distinct financial system designs and their persistence in the absence of regulation. Answers to such puzzles may hinge both on making advances in theoretical modeling and on assembling a wider range of evidence. Neither political nor legal structure is clearly independent of economic backwardness, and the three factors may be mutually enhancing, rather than mutually exclusive.

Thus, the existing literature leaves room for both economic and political-legal factors in financial development. The following sections attempt to evaluate both types of influences on financial system structure and economic growth. As in the existing literature, the analysis treats these factors as exogenous in a statistical sense. In doing so, the discussion avoids the rather thorny issue of the genesis of economic 'backwardness,' legal traditions, and political organization; a problem for which neither economics nor political science offers methods for quantification. 


\section{Empirical Classifications of Financial Systems}

The literature on comparative financial systems sets out a fairly strict dichotomy between market-based and bank-dominated systems. While this distinction offers a useful tool for organizing debate, the prevalent typology, as laid out by Dietl (1998), for example, is far more stylized than the reality. History offers interesting insights into the multiplicity of financial system designs and the lack of tight links among various banking characteristics. Table 1 demonstrates this point by cataloging several characteristics and practices: universality, seats on company boards, non-financial equity share-holding, proxy voting of non-financial shares, and extensive branching networks-for 26 national financial systems for various time periods. ${ }^{10}$

The clearest pattern is the prevalence of extensive, national branch networks around the world by the early twentieth century. Only Portugal, Denmark, Norway, and the United States failed to develop such branching before World War I. Explaining the absence of branching is easy for the United States (regulation), but less simple for the other three countries. While the U.S. imposed a variety of restrictions on branching, the first three countries did not. Their lack of branching might be attributed to lack of economic development, except that many far poorer countries, such as India, Brazil, Mexico, and Japan, did maintain branch networks. ${ }^{11}$ Moreover, though these three non-branching countries were on the European periphery, so were several branching countries: Spain, Russia, Finland, and Sweden, for example. Finally, even though these three countries were all small with small industrial sectors, so were New Zealand, Finland, Ireland, and Greece. In any case, by the early post-World War II years, only the U.S. perpetuated the unit banking system in many parts of the country-and even then branching within states was taking hold in several states. ${ }^{12}$

Given the near ubiquity of branching among the countries surveyed, it is clear that branching practices are related to neither the institutional structure of commercial or industrial banks nor the political-legal system in place. National branch networks evolved in most cases at the very end of the nineteenth century, perhaps in response to the increased benefits of scale in finance. Technological advances during the last quarter of the century probably encouraged increasing scale of both industry and financial institutions, and enlarging individual bank resources began to depend on gathering resources from a wider base. Hence, branching arrived

\footnotetext{
${ }^{10}$ The determination of banking characteristics stems from exhaustive searches of secondary literature for most of the countries listed. For Germany and Italy, the determination is based also on my own original research.

${ }^{11}$ Apparently, Brazil imposed restrictions on inter-state branching by domestic banks but permitted branching within states. Foreign banks could branch as they pleased.

${ }^{12}$ See Calomiris (2000, forthcoming) for a collection of his previous articles dealing largely with branching and relevant political and regulatory debates.
} 
hand in hand with the pursuit of the deposit business by commercial banks. ${ }^{13}$ Branching into new geographical regions, since it allowed greater diversification of banks' assets and liabilities, may have also accelerated in response to the widespread financial crises of the early 1890s. These economic influences pervaded most of the industrialized or industrializing world and in nearly all cases superceded the special interests generated by fragmented political power and the centrifugal forces of common law traditions.

The findings here also indicate that branching is neither necessary nor sufficient for universal banking to arise. Indeed, universality arose most places in the first half of the nineteenth century, long before the impulse to branch struck. Despite some modern arguments to the contrary, universality of banking services required a very modest minimum scale of operations, as evidenced by the success of many private bankers. Even joint-stock universal banking succeeded in (nearly) unitary organizations into the twentieth century. Two cases illustrate this point: Germany developed joint-stock universal banking at least by 1850 but, like most other countries, created widespread branch networks only in the 1890s; England, on the other hand, maintained specialized deposit and investment banking even throughout most of the twentieth century, but developed an extensive nationwide branching system along with the universal-banking countries.

Universality, though not as ubiquitous as branching, spread over many parts of the world in the nineteenth century. The Belgian case displays a pattern common in many moderately industrialized countries of the mid- to late-nineteenth century: a small number of large-scale, typically limited-liability universal banks augmented by generally smaller specialized banks focusing more on a narrower range of services. To varying degrees, this mixture of institutions emerged elsewhere in continental Europe (at least in Denmark, France, Greece, Italy, the Netherlands, Spain, Sweden, and Switzerland), parts of Latin America (Argentina, Brazil, and Mexico, for example) and, in a limited way, even in Australia, New Zealand, and the United States before various financial crises and regulatory actions damped it out. Germany, with its dozen or more large-scale universal banks, remained at the extreme until the major concentration movement of World War I.

During this same period, however, formalized relationship banking characteristics-the activities such as representation in non-financial corporations' boards, direct equity stakeholdings in non-financial firms, and proxy voting of customers' shares that are often identified with the German banks-were far less common than might be expected. Until the 1860s and 70s, when incorporation became freer in many parts of the world, and corporate governance institutions like supervisory boards gained prominence, few opportunities arose for intimate, formal bank connections. There are actually very few studies that quantify the extent of these practices, but the qualitative descriptions available suggest that most banks took little role in non-financial

\footnotetext{
${ }^{13}$ On changes in banks' funding sources in Germany, Italy, and England, see Fohlin (2001, forthcoming) and (1999b).
} 
corporate governance for most of the nineteenth century. Thus, even in countries with universal banks, practices that are now seen as enforcement mechanisms for long-term bank-firm relationships, such as equity stakes and board seats, varied quite a bit in their importance. At least in Germany, and apparently also in Belgium, France, and likely elsewhere, universal banks in the 1850s often took over the capital of a few firms for which the banks were managing a new issue. The down markets of the mid- to late-1850s left the banks holding major stakes in a few firms, and the ensuing losses taught these banks to avoid such costly mistakes in the future (prominent examples include the French Credit Mobilier and the German Discontogesellschaft and Darmstädter Bank). These participations were largely accidental, and were not pursued as a means of corporate control.

Many countries took to relationship banking practices much more actively around the turn of the twentieth century, long after the advent of universality; but even then, it appears that direct equity stakes and board positions were limited to a small proportion of firms. Certainly German, Austrian, and Italian universal banks took positions in firms' boards, but the vast majority of at least German joint-stock companies received no representation from banks. ${ }^{14}$ Bankers also took up board positions in primarily specialized systems, such as Canada, Finland, Greece, Japan, the U.S., and probably also Belgium, France, and Italy during the middle of the twentieth century, when many of these countries underwent regulatory restraints on universality.

The fact that universal banking existed without widespread relationship banking (at least nine of the 26 cases of universal banking) suggests that the latter is not necessary to insure the viability of the former. Moreover, in many cases, it is clear that firms had occasion to patronize multiple banks, and that they took advantage of those opportunities. Because of the size of their securities issues, the largest public firms in particular used financing from, and often received board representation from, several different banks. Thus, the historical experience also suggests that universality is not even clearly based on exclusive, long-term interaction with firms. This institutional independence is important, because some (see Calomiris, 1995, for a review) have hypothesized that formal institutions help enforce repeated interaction between individual firms and a single bank-the housebank idea-that in turn yields informational economies of scope and lower costs of finance for industrial firms. Likewise, the engagement of specialized banks in board positions further indicates that relationship banking was motivated by factors other than insuring informational economies of scope.

The oversimplified schema of financial systems also categorizes countries as either bank-based or market-based, with a presumed association between universality and bank dominance. While it is exceedingly difficult to gather comprehensive historical measures of securities market activity, the qualitative evidence and

\footnotetext{
${ }^{14}$ See Fohlin (1997, 1999a - EHR).
} 
the data available for a few countries both undermine this neat classification. Before World War I, most industrializing economies supported thriving secondary markets for securities. Even some of the poorest economies, such as India, Russia, and Brazil, had one or more relatively active financial markets. Only a few countries-Finland, New Zealand, Norway, for example-had virtually no markets. Clearly, financial markets emerged regardless of banking design. The main international markets of the late nineteenth and early twentieth centuries were London, Paris, New York, and Berlin. In 1905, moreover, approximately 30 percent of the 5,500 German joint-stock companies held listings on one or more German exchange-with the majority of these listings in Berlin. Thus, the archetypal universal banking system, Germany, was at least partially market based.

It should actually come as no surprise that universal banking systems support active securities markets, if one considers the primary characteristics of universality: combination of investment and commercial banking. The existence of full-scale universal banks requires the use of securitized financial instruments. A universal bank will have little investment banking business if it has no underwriting and brokerage services to perform. The existence of markets in which to trade securities facilitates the use of these claims and therefore promotes the investment side of the universal banking business. There are also obvious ways in which banks and markets compete, in both the initial placement and the ongoing trading of securities, and there are probably cases in which the activities of universal banks impinged on the operation of the market. For example, universal banks that provided brokerage services may have traded securities among their customers and taken only the net transaction to the market. In the German example, a tax loophole that failed to impose trading taxes on all orders, even executed through banks, allowed Berlin-based universal banks to offer savings to their customers who traded through them instead of through smaller intermediaries or brokers. The more trades the banks could gather and net out within their own client networks, the further the eventual net trading fees were spread. This loophole was closed by 1900, but even before that, it did not prevent the expansion of the Berlin exchange. This example, however, may say more about the sometimes idiosyncratic influences of government than the innate substitutability of financial markets and universal banks. ${ }^{15}$

\footnotetext{
${ }^{15}$ Germany provides a wealth of examples of government intervention in financial markets and institutions, including requirements on stock market listing, levying of taxes on issues and trades, and imposition and removal of a ban on futures trading on nearly all industrial shares. See Fohlin (2000).
} 


\section{Evolution of Systems}

The identification of universality with bank domination and specialization with market domination likely stems from two forms of myopia: focus on the post-World War II era, and narrowness in the range of cases examined. The typology is usually based on comparisons of the United States, Great Britain, Germany, and sometimes Japan in the 1950s through 1980s. The first two countries, having hosted the most important international financial markets for much of the twentieth century and having eschewed both universal banking and formalized bank relationships for most of that time (particularly in the U.S. post-war), head up the marketbased, specialized, arms-length group. Germany and Japan, with their enormous banks and widely-cited networks of clients and house-bank relationships, lead the bank-dominated, universal, relational group. Even these cases, however, defy rigid classification, since closer scrutiny reveals the lack of widespread, exclusive house-bank relations in Germany, the frequent presence of bankers in American boards of directors, as well as both the lack of universality and the size and activity of the securities market in Japan, for example.

Moreover, many systems underwent significant upheaval in the aftermaths of the two World Wars, so that some systems changed significantly during the inter-war and early post-war years. Banking institutions in a number of countries suffered both political and economic consequences of war and depression. Many countries enacted legislation in response to political pressure in the 1920s and 30s, and countries such as Belgium, Greece, Italy, Japan, and the United States went so far as to legally prohibit full-scale universal banking. At the same time, economic and political crises hit financial markets, particularly in the early 1930s and during and after World War II. Rajan and Zingales (1999) suggest that governments, because they could exert less control over markets than over firms, and because of the growing discontent of their constituents, found ways to effectively hinder or even shut down markets of all sorts. These authors argue, further, that the extent of the anti-market backlash varied most significantly with the legal-political system: civil law countries being more susceptible to centralizing command and control than common law countries.

Germany presents, again, one of the most striking examples. The fallout of World War II, causing the cession of vast portions of eastern German industry and resources, along with the very site of the primary stock exchange (and important provincial exchanges), could hardly avoid the near obliteration of the vibrant Berlin market of the pre- and early post-World War I era. The weight of foreign occupying powers, the urgent bailouts of industrial firms by financial institutions, the strengthening of the social-welfare state, the imposition

of hefty capital gains taxes on sales of shares, and other exigencies of post-war reconstruction conspired to produce a financial system in which banks were extremely large, industry partly subordinated its ownership 
and governance to financial institutions, and markets failed to flourish. Yet, given the country's unique position in the events of the 1930s and 40s, Germany is unlikely to represent the experiences in most other countries-even those with universal banks. Thus, concentrating on Germany as the paradigm case of a universal banking system likely skews the perception of the organization and operation of such systems in general.

The move away from universality varied in its implementation and lasted only a few decades even where it was enforced. By the 1990s, most systems had reverted to something resembling their pre-World War I state (see Table 2). Using the traditional meaning of universal banking-the combination of investment and commercial banking by one institution-banking structure in 1990 is extremely highly correlated with structure in 1913.For those countries that had begun to industrialize by the mid-nineteenth century, the correlation persists back to at least 1850 . Of the 26 cases summarized in Table 2, no system clearly and permanently switched from one category to the other over this period of 100 to 150 years. This evidence of path dependency is all the more impressive in light of government interventions specifically intending to alter institutional design.

Despite much continuity, of course, bank structures have evolved over time. The three-choice bankstructure variable reflects this change and suggests some international convergence in the organization of banks. Most banking systems, whether universal or not in the pre-war era, underwent a conglomeration movement starting in the 1970s. This development created quasi-universal banking in nearly all industrialized countries, in the sense that financial institutions of several types began operating under the umbrella of a bank holding company. Thus, even the steadfastly specialized system of England is home to financial services conglomerates. Likewise, the traditionally universal systems of Germany, Belgium, and many other continental European countries have outgrown the single-unit universal banking form, so that the commercial and underwriting arms of banks are less closely integrated.

\section{Determinants of Financial System Design}

The previous two sections raised a number of theoretical and empirical questions on which further analysis may shed some light. In particular, it remains to be determined whether systematic relationships emerge among legal, political, economic, and financial characteristics of countries. 


\section{Models and Testable Implications}

1. Gerschenkron's work yields few concrete, testable implications. One such hypothesis, though, is that financial institutions play a more important role the more backward the economy at the outset of industrialization. David Good (1973) offered early testing of this and related hypotheses. Specifically, Good interpreted Gerschenkron as implying either that the level of banking development at the end of the 'great spurt' of industrialization or the growth rate of the banking sector during the 'great spurt' relates positively to the extent of backwardness at the time of initiation of industrialization. Gerschenkron insisted that his theory applied to continental Europe in the nineteenth and early twentieth centuries, therefore tightly constraining the number of cases available for empirical tests. The narrowness in the applicability of his hypothesis naturally limits its usefulness in drawing lessons from history. It is helpful therefore, to seek more general hypotheses linking economic conditions to the development and design of financial systems-for example, by investigating other areas and time periods.

One problem with this whole line of research is the notion of a 'great spurt' of industrialization. More and more, researchers are determining that industry developed more gradually and with less discontinuity than was thought in the 1950s and 1960s. Still, it is clear that certain economies had reached a much more developed state by the last quarter of the nineteenth century than had others. By examining the level of financial development around 1880 and its growth in the succeeding twenty years, we can capture the parabolic relationship between economic and financial development. For Europe in 1880, the most and least developed economies should have the lowest rates of financial system growth, while the moderately advanced economies should have the highest rates. The level of financial development may be high in the most industrialized economies, but it should certainly be high in the moderately-advanced economies and low in the least advanced. Using rates of growth of the economy, rather than levels, should yield an essentially linear relationship between economic and financial development: the fastest growing economies should have the most rapid financial development. In the traditional view, slow growers include both those that have passed their earliest phases of industrialization and those that have so far failed to industrialize. If the hypothesis is true more generally, then the U-shaped relationship between financial system growth and economic development should hold in different time periods and for all countries. The results of these tests (discussed subsequently) can neither prove nor disprove Gerschenkron's hypothesis about economic backwardness and financial institutions, but they will at least provide some tentative evidence for or against. 
2. Verdier's argument relates political structure to universality, and again specifies a non-linear relationship. Universality is hypothesized to be more likely the stronger the lender of last resort facility of the central bank, but less likely the more centralized the market for deposits. These proximal causes for universality therefore imply an inverted $U$ correspondence between state centralization and universality. Verdier's argument is couched in an historical perspective, and it is not clear that it applies generally. More specifically, the argument relates to the role of state centralization at the inception of the financial system; it does not specify a permanent relationship between the two variables. The argument should hold well in the 1880-1913 period, when financial system development was fresh, but might hold more loosely thereafter. For example, changes in state centralization may not alter the shape of the financial system, if institutions exhibit strong path dependency. Alternatively, exogenous shocks may alter financial system design, even though state centralization remains stable.

3. Implicit in La Porta et al $(1997,1998)$ and Dietl (1998) is the idea that, for reasons related primarily to investor protection and tendencies for centralization of power, the growth (and, implicitly, the design) of financial systems are correlated with legal tradition. In general, financial development proceeds faster and markets supercede banks in common law countries. Rajan and Zingales (1999) argue that the causal link is weak, and may relate more to the role of state centralization. Nonetheless, civil law traditions may favor greater centralization of power, making it difficult to disentangle the links among legal, political, and financial variables.

\section{Financial System Variables}

The foregoing sets of hypotheses specify three different types of financial system variables: financial development, market orientation, and universality of banking.

1. Financial system development. Financial system development is measured as both the level and growth rate of aggregate financial assets (normalized by GDP) in a country at a given point in time or over a specific period of years. Because of the lack of sufficient data on stock market capitalization for the current sample of countries, the figures here include Goldsmith's (1969) compilation of assets held by financial institutions.

2. Market orientation. Market orientation is more difficult to measure. The composite measure in Levine (2000), is aimed at distinguishing bank-based from market-based systems in the 1990s, but the variable provides a few puzzling results. For example, using the binary indicator variable formed by breaking the 
continuous measure at the median, Brazil, Denmark, Germany, the Netherlands, Sweden, and Switzerland are all classified as 'market-based,' despite the traditional presence of large-scale universal banks in these countries. This mismatch may be interpreted two ways: either the 'banks-versus-markets' dichotomy corresponds poorly to the 'universal-versus-specialized' split, or this particular measure fails to capture either phenomenon. Given the extremely high correlation between the binary system variables for 1913 and 1990 demonstrated in the previous section, I assume for the sake of argument that the continuous variable in Levine (2000) applies similarly in 1913. I emphasize that I am not assuming that the variable accurately represents the absolute level of 'market-orientation' in 1913, but rather that the variable roughly approximates the relative extent of 'market-orientation' of the systems at that time. In the absence of the necessary data to create such a composite, quantitative variable for 1913, this measure is the next best proxy.

The figures presented in Rajan and Zingales (1999) demonstrate similar problems. Their calculations of stock market capitalization relative to GDP in 1913 place the U.K, Japan, and Germany as the top three markets, followed closely by Switzerland, Italy, and Norway. The U.S. and France, considered two of the most important markets of the time, appear in the same league as Belgium and Spain and lie closer to Finland and Hungary than to their qualitative peers. Given the number of countries not covered by the underlying sources, I do not use these data in the econometric analysis.

3. Universality. The previous section noted the difficulty of classifying countries using a binary financial system variable, yet other recent research indicates the trouble inherent in quantitative measures. Verdier (1999), for example, uses the ratio of commercial bank equity to deposits as a proxy for universality, but again, that measure corresponds inconsistently to a qualitative assessment of the prevalence of universal banks in the economy. The analysis here uses the two- and three-choice indicator variables given in Table 2 as well as Verdier's equity-deposit ratio.

\section{Other Variables}

1. Economic factors. Economic factors are the most straightforward to quantify, though of course data availability, particularly for the early- to mid-nineteenth century, varies from country to country. Gross domestic product per capita, measured in 1990 Geary-Khamis dollars comes from Maddison (1995). From these figures, I measure growth rates of GDP per capita for several sub-periods as the coefficient estimate on a time trend when the log of GDP per capita is regressed on a constant and that trend variable. Employment in various sectors of the economy-agriculture, industry, and finance or commercial-come from Mitchell 
(1983). After constructing the ratio of industrial to agricultural employment, I calculated the percentage growth of the ratio from 1880 to 1913 . These measures permit quantification of the distribution of resources to different sectors and the development of industry relative to agriculture. Finally, industrial development is measured as the product of GDP per capita and the industrial/agricultural employment ratio. The purpose of this variable is to measure not just the wealth, but the combination of wealth and industrial development, in the sample of countries.

2. Political factors. Political characteristics mean the nature of the political system, not the frequency or nature of individual political events. Centralization of power is the main feature of importance in the theories presented. Verdier measures centralization by the share of total government revenues collected by the central government. It is difficult to quantify centralization, of course, yet this variable seems a reasonable proxy. Unfortunately, lack of data on government revenues in the pre-war period limits the number of cases that can be included.

3. legal factors. Legal factors boil down to common versus civil law traditions, measured by a simple binary indicator taking the value one for common law countries and zero for all versions of civil law. Given the small sample of countries, further division into types of civil law would divide the sample too finely.

\section{Results}

Given that we are dealing with national data in a period before large-scale accounting, the sample is naturally limited. The problem is severe enough in the period before 1880 as to essentially rule out statistical analysis of the data. Nonetheless, several clear relationships emerge in the data, and they offer important insights into the three sets of hypotheses laid out previously.

1. Economic factors. In this interpretation of the Gerschenkron hypothesis, we should expect to find an inverted U-shaped relationship between GDP per capita in 1880 and the level of financial system assets in both 1880 and 1900. Such a relationship does emerge among the 14 to 19 countries for which there is sufficient data (Table 3). The coefficient estimates, based on robust regression (using a Huber/bi-weight limited-influence estimator), are much more statistically significant for 1900 than for 1880 . The industrial development measure performs relatively poorly.

Along this same line of reasoning, the growth rate of financial assets should be negatively associated with the level of GDP per capita in 1880. This hypothesis is born out both for the growth of financial assets from 1880 to 1900 and from 1900 to 1913 . Level of GDP per capita in 1900 is also negatively related to 
financial system asset growth over the succeeding 13 years. Particularly interesting, the rate of growth of GDP per capita from 1880 to 1900 relates very strongly and positively to the growth of financial system assets over the following period (1900 to 1913). The reverse relationship-from financial system asset growth to GDP per capital growth-does not emerge.

A corollary to this hypothesis is the idea that market orientation is related to the level of development. Indeed, in the current sample, a U-shaped relationship emerges between the structure index reported in Levine (2000) and GDP per capita in both 1880 and 1900. For most of the range of GDP per capita, the structure index is increasing, suggesting that for the most part market orientation is increasing in the level of development. This result is particularly remarkable, as it strongly supports the idea of path dependency in the structure of financial systems: the explanatory variables predate the dependent variable by 90 to 120 years.

2. Political factors. Given the results and discussion in Verdier (1999), it is not surprising that a Ushaped relationship does not emerge between the equity-deposit ratio and state centralization for the 14 countries for which the data are available (Table 4). This statistical weakness may stem from a lack of an underlying relationship or simply from the dearth of data. Interestingly, the economic variables included as controls attain markedly higher statistical significance than does state centralization. Columns three and four indicate that universal banking was more likely in countries with lower levels of GDP per capita in 1880 and with higher rates of growth of GDP per capita between 1880 and 1900. While this finding tends to support a Gerschenkron-inspired view of the importance of large-scale industrial banking for late-nineteenth century industrializers, the statistical significance varies depending quite a bit depending on the measure of universality used. Somewhat contrarily, growth of industrial employment relative to agriculture (from 1880 to 1913) relates negatively to the probability of universality. One would expect, in the Gerschenkron line of thinking, that the opposite relationship would hold. Again, however, the statistical power is low.

In line with the narrative arguments of Rajan and Zingales (1999), State centralization (in 1880) relates very significantly and negatively to market orientation (in the 1990's). Given the long time lag between the dependent and independent variables, the findings further bolster the idea of path dependency in financial system structure.

3. Legal tradition. Adherence to common law principles is argued to promote market development and support financial markets in particular. The results here suggest that market orientation (as measured by the 1990's structure index) is far higher in common law countries, and that financial institution growth in the preWorld War I period was higher (though statistically not very significantly) in civil law countries. Common law is also seen as possibly hampering the centralization of state power, but the findings here support this idea 
very weakly: the ratio of central to total government revenues is only slightly higher in civil law countries than in common law countries ( 0.69 versus 0.58 ), but the p-value of a one-sided t-test is only 0.15 (Table 5).

The cross tabulation results indicate clearly that full-scale universal banking is absent in common law countries, while completely specialized intermediaries do not arise in civil law countries. This split is most relevant and pronounced in the historical period, before the conglomeration movement of recent years. It is tempting to argue that market promotion tends to foster the development of institutional substitutes, so that we should expect to find that civil law countries are more prone to universal banking than are common law countries. On the other hand, it may be more realistic to point out that the common law countries are virtually all related to England in various ways and adopted and adapted many institutions and norms from the mother country. In this sample, the four strictly specialized systems are England, Australia, New Zealand, and Ireland. When the 1913 world is divided into just two camps, the specialized category includes also Canada, the U.S., and India. Argentina, Mexico, and Norway-all with arguable ties to England, but with civil law traditions-round out the specialized group of countries. Regardless of the underlying impetuses for universality or specialization, the findings here (the three-choice indicator) once again emphasize the fact that the majority of financial systems fall somewhere in between the two extremes.

Moreover, the results here also hint at the issue of the economic consequences of legal system design. Such debates are typically motivated by the idea that certain systems may promote greater efficiency and economic well-being than others. Certainly, there are advocates of specific types of systems. Yet the typical measure of prosperity of an economy, the rate of growth of GDP per capita, does not vary systematically with the adherence to a particular legal system (Table 5). While common law countries grew faster in some subperiods, civil law countries grew faster in others. Recalling the high correlation between legal and banking system type, these periodic advantages and disadvantages trace back to obvious origins-such as periods of industrialization or post-war reconstruction. Over the 1980's and early 1990's, however, growth rates were statistically identical.

\section{Conclusions}

The goal of this paper is to broaden the existing perspective on the factors involved in the design and development of financial systems internationally. The classification of the 26 sampled countries by type of financial system yields several interesting patterns. In the first section of the paper, the results demonstrate the diversity of financial system designs and the difficulty of dividing the world into universal or specialized 
categories. Many economies undergoing industrialization in the mid- to late-nineteenth century supported a small number of large-scale, universal banks but maintained many more specialized banks as well. Nationwide branching appeared in most countries between the 1890s and World War I, and only the United States persisted in widespread unit banking after World War II. Formalized relationship banking through interlocking directorships arose around the same time period, but seems to have involved a relatively small portion of firms. Relationship banking has been more common in universal systems but the two institutional features have clearly existed independently of one another. Certainly, there has been no link between branching and the design of banking institutions, political system, or legal tradition.

The analysis also points out that the link between universality and limited securities markets-to the extent that it exists-is a post-World War II phenomenon. Most industrialized economies maintained significant securities markets in the pre-war era, and some of the most important markets of the time were ensconced in at least partially universal systems. This alteration in the prevalence of markets is much more persistent than changes in banking design. No system surveyed permanently switched from universal to specialized, so that banking structure has demonstrated remarkable path dependency over the past 100-150 years. At the same time, financial conglomerates have emerged in most industrialized economies. This relatively recent phenomenon appears to be dictating the convergence of financial system design: formerly specialized systems are becoming ostensibly more universal, while traditional universal banks are less truly universal. Thus, informational economies of scope-the idealized view of cradle to grave financing by an individual banker or close-knit group of financiers-hardly describes any financial system in modern, industrial economies.

The second part of the analysis uncovers several patterns in the development of financial systems and helps to disentangle some of the economic, political, and legal forces involved. Financial institution structure and development clearly relate to previous economic development in the countries and period observed, but the converse relationship does not hold. This is a particularly interesting result in light of the more recent literature on the causal relationship between financial and real growth. The inverted U-shaped relationship between financial institution assets and GDP per capita lends support to the idea that the moderately industrial countries of the time depended more on financial institutions to mobilize capital than did the most and least advanced economies. These relationships hold all the more robustly when non-European countries are included. Given the small sample sizes, it is difficult to determine whether this added statistical strength stems solely from the increase in the number of countries included. Whether these tests address the so-called Gerschenkron hypothesis is open to debate, but the results do seem supportive of his general ideas. The consistency of the relationship over different time periods presents a useful avenue for future research. 
Quantifiable political factors, such as government centralization, provide very little power in explaining banking system design, but do strongly relate to market orientation. Nonetheless, many individual country histories make it clear that political forces played important roles in shaping regulations that in turn altered the course of financial institutions and markets. The results here simply suggest that these political forces appeared inconsistently and had no traceable, uniform relationship to the overall political system in place in the nineteenth century.

Legal traditions, in contrast, correlate highly with both market orientation and banking institution design (but not government centralization). It seems very likely, however, that the legal system variable may coincidentally proxy for the true source of influence on the financial system-whether adoption from colonizing powers, adaptation from neighbors or trading partners, or innate cultural and social beliefs. Moreover, legal orientation exerted little impact on financial institution growth at the turn of the century and provides no consistent prediction of real economic growth rates over the past 150 years.

These results underscore the two themes set out in the introduction: the weight of history in determining the growth and design of financial institutions and markets, and the importance of idiosyncratic forces that buffet institutions over time. Despite obvious connections among political, legal, economic, and financial institutions, robust, long-term, causal relationships often prove to be elusive. 


\section{References}

Allen, F. and D. Gale, (2000), "Comparing Financial Systems." Cambridge, MA: MIT Press.

Allen, F. (1992), "Stock Markets and Resource Allocation." in Capital Markets and Financial Intermediation. Cambridge: Cambridge University Press.

Boot, A. W. A. and Thakor, A. V. (1997), "Financial System Architecture," Review of Financial Studies 10, pp. 693-733.

Boot, A. W. A. and Thakor, A. V. (1997), "Banking Scope and Financial Innovation." Review of Financial Studies 10, 1099-1131.

Boyd, J.H., and B.D. Smith (1994), “Capital Market Imperfections, International Credit Markets, and Nonconvergence," Journal of Economic Theory 73, pp. 335-64.

Boyd, J.H., and B.D. Smith (1995), “The Evolution of Debt and Equity Markets in Economic Development." Working paper 542, Federal Reserve Bank of Minneapolis.

Boyd, J., and B. Smith (1996), "The Coevolution of the Real and Financial Sectors in the Growth Process." The World Bank Economic Review 10, 371-396.

Calomiris, Charles (1995), "The Costs of Rejecting Universal Banking: American Finance in the German Mirror, 1870-1914." In Naomi Lamoreaux and Daniel Raff (Eds.) Coordination and Information: Historical Perspectives on the Organization of Enterprise, 257-315. Chicago: University of Chicago Press.

Calomiris, Charles W. (2000), "U.S. Bank Deregulation in Historical Perspective." Cambridge: Cambridge University Press.

Capie, Forrest (1999), "Banking in Europe in the nineteenth century: the role of the central bank." In Richard Sylla, Richard Tilly and Gabriel Tortella (Eds.) The State, the Financial System, and Economic Modernization, 118-133. Cambridge: Cambridge University Press.

Dewatripont, M., and Maskin, E. (1990), "Contract Renegotiation in Models of Asymmetric Information," European Economic Review 34, pp. 311-321.

Diamond, D. (1991), "Monitoring and Reputation: The choice between Bank Loans and Directly Placed Debt," Journal of Political Economy 99, 689?721.

Dietl, Helmut (1998), Capital Markets, New York: Routledge.

Fohlin, C. (1997a), "The Universal Banks and the Mobilization of Capital in Imperial Germany," forthcoming in P. Cottrell, G. Feldman, \& J. Reis (Eds.), Finance and the Making of Modern Capitalism. Aldershot: Scolar Press.

Fohlin, C. (1997b), "Universal Banking Networks in Pre-War Germany: New Evidence from Company Financial Data," Research in Economics 51, pp. 201 ?225. 
Fohlin, C. (1997c), "Universal versus Specialized Banking Structures: Insights from British and German Bank Balance Sheets before World War I." Social Science Working Paper No. 1016, California Institute of Technology.

Fohlin, C. (1997d), "Bank Securities Holdings and Industrial Finance before World War I: Britain and Germany Compared." Business and Economic History 26, 463-475.

Fohlin, C. (1999a), "The Rise of Interlocking Directorates in Imperial Germany." Economic History Review, 11, 307-333.

Fohlin, C. (1999b), "Capital mobilisation and utilisation in latecomer economies: Germany and Italy compared." European Review of Economic History, 2, 139-174.

Fohlin, Caroline, (2000), "Company Law, Stock Market Regulation, and the Development of the German Financial System," Social Science Working Paper 1065, California Institute of Technology.

Fohlin, C., (2000, forthcoming), "The Balancing Act of German Universal Banks and English Deposit Banks, 1880-1913." Social Science Working Paper 1016R. California Institute of Technology.

Friedrich, W. (1979), “Die Entwicklung des Rechts der bergrechtlichen Gewerkschaft in Preußen von 1850 bis zum Ersten Weltkrieg," In N. Horn and J. Kocka (eds.), Recht und Entwicklung der Großunternehmen im 19. Und frühen 20. Jahrhundert, Bielefeld, Germany: Göttingen: Vandenhoeck \& Ruprecht.

Galetovic, Alexander (1996), "Finance and Growth: A Synthesis and Interpretation of the Evidence." BNL Quarterly Review 196, 59-82.

Gerschenkron, A. (1962), Economic Backwardness in Historical Perspective, Cambridge, MA: Harvard University Press.

Gerschenkron, A. (1968), "The Modernisation of Entrepreneurship." In: Continuity in History and Other Essays, Cambridge: Belknap Press of Harvard University Press, 137.

Gerschenkron, A. (1970), Europe in the Russian Mirror, New York: Cambridge University Press.

Goldsmith, R. (1969), Financial Structure and Development, New Haven: Yale University Press.

Good, David (1973), "Backwardness and the Role of Banking in Nineteenth-Century European Industrialization," The Journal of Economic History 33, 845-850.

Greenwood, J. and Smith, B. D. (1997), "Financial Markets in Development, and the Development of Financial Markets." Journal of Economic Dynamics and Control 21, 145-181.

Gurley, John G. and Shaw, Edward S. (1955), Financial Aspects of Economic Development, The American Economic Review, v. XLV, number 4, pp. 515-538. 
Harley, C. Knick (1991), "Substitution for prerequisites: endogenous institutions and comparative economic history." In Richard Sylla and Gianni Toniolo (Eds.), Patterns of European Industrialization. London and New York: Routledge. 29-44.

Horn, N. (1979), "Aktienrechtliche Unternehmensorganisation in der Hochindustrialisierung (1860-1920). Deutschland, England, Frankreich und die USA im Vergleich." In N. Horn and J. Kocka (Eds.), Recht und Entwicking der Großunternehmen im 19. Und frühen 20. Jahrhunder., Bielefeld, Germany: Göttingen: Vandenhoeck \& Ruprecht.

Horn, N. and J. Kocka (1979), Recht und Entwicking der Großunternehmen im 19. Und frühen 20. Jahrhundert, Bielefeld, Germany: Göttingen: Vandenhoeck \& Ruprecht.

Jappelli, Tullio and Pagano, Marco (1994), "Saving, Growth, and Liquidity Constraints." The Quarterly Journal of Economics 109. 83-109.

Jayaratne, Jith and Strahan, Philip E. (1996), "The Finance-Growth Nexus: Evidence from Bank Branch Deregulation," The Quarterly Journal of Economics 111, pp. 639-670.

Kennedy, W. P. (1992), "Historical Patterns of Finance in Great Britain: A Long-Run View." In V. Zamagni (Ed.), Finance and the Enterprise. London: Academic Press.

King, Robert G. and Levine, Ross (1993), "Finance and Growth: Schumpeter Might be Right," The Quarterly Journal of Economics 108, pp. 717-737.

King, Robert G. and Levine, Ross (1993), "Finance, Entrepreneurship, and Growth: Theory and Evidence," Journal of Monetary Economics 32, 513-542.

La Porta, R., Lopez-De-Silanes, F., Shleifer, A. and Vishny R. W. (1997), "Legal Determinants of External Finance.” The Journal of Finance 52. 1131-1150.

La Porta, R., Lopez-De-Silanes, F., Shleifer, A. and Vishny R. W. (1998), "Law and Finance.” Journal of Political Economy, 106, 1113-1155.

La Porta, R., Lopez-De-Silanes, F., and Shleifer, A. (1999), "Corporate Ownership Around the World.” The Journal of Finance, 54. 471-517.

Levine, Ross (2000), “Bank-Based or Market-Based Financial Systems: Which is Better?” Finance Department Working Paper, University of Minnesota.

Lucas, R.E., Jr. (1988), "On the Mechanics of Economic Development," Journal of Monetary Economics 22, $3-42$.

Maddison, A. (1995), Monitoring the World Economy 1820-1992, Paris: OECD.

McKinnon, R. (1973), Money and capital in economic development. Baltimore: The Brookings Institution. 
Mitchell, B. R. (1983), International Historical Statistics: The Americas and Australasia. Detroit: Gale Research Company.

Mitchell, B. R. (1983), International Historical Statistics Europe 1750-1988. 3rd Edition. New York: Stockton Press.

Pagano, Marco (1993), "Financial Markets and Growth: An Overview," European Economic Review 37, 613-622.

Rajan, Raghuram, (1992), "Insiders and Outsiders: The Choice Between Informed and Arm's Length Debt", Journal of Finance 47, 1367?1400.

Rajan, R.G. and L. Zingales (1997), “Financial Dependence and Growth," University of Chicago \& NBER. Rajan and Zingales (1999), "The Politics of Financial Development." Working paper, University of Chicago and NBER.

Reich, N. (1979), "Auswirkungen der deutschen Aktienrechtsreform von 1884 auf die Konzentration der deutschen Wirtshaft," In N. Horn and J. Kocka (eds.), Recht und Entwicklung der Großunternehmen im 19. Und frühen 20. Jahrhundert, (Göttingen).Pp. 257-263.

Robinson, J. (1952), The generalization of the general theory, in The rate of interest and other essays. London: Macmillian.

Schumpeter, Joseph (1912), Theorie der wirtschaftlichen Entwicklung. Leipzig: Duncker \& Humblot.

Shaw, E. (1973), Financial deepening in economic development. Oxford: Oxford Univ. Press.

Story, Jonathan and Walter, Ingo (1997), Political economy of financial integration in Europe. Cambridge, MA: The MIT Press.

Sylla, R. E. (1991), "The Role of Banks," In Richard Sylla and Gianni Toniolo (Eds.), Patterns of European Industrialization. London and New York: Routledge. 45-63.

Thakor, A. V. (1996), "The Design of Financial Systems: An Overview." Journal of Banking and Finance 20, 917-948.

Tilly, R. (1994a), “German Banks and Foreign Investment in Central an Eastern Europe before 1939." In D. Good (ed.), Economic Transformations in East and Central Europe, London and New York.

Tilly, Richard (1994b), “'Banks and Industry: Lessons from History." Paper presented at European Economic Integration as a Challenge to Industry and Government, Münster, Germany.

Verdier, Daniel (1997), "The Political Origins of Banking Structures." Policy History Newsletter 2.

Verdier, Daniel (1999), "The Origins of Universal Banking in 19th Century Europe, North America and Australia." European University Institute, mimeo. 
von Thadden, E. I. (1990), Bank Finance and Long-Term Investment," WWZ Discussion Paper 9010, University of Basel.

Wilson, P. (1994), "Public Ownership, Delegated Project Selection and Corporate Financial Policy." Working paper, Indiana University.

Ziegler, D. (1993), "Zentralbankpolitische Steinzeit? Preußische Bank und Bank of England im Vergleich," In Geschichte und Gesellschaft 19, 475-505. 
Table 1. Banking System Characteristics in International Perspective: the Nineteenth and Twentieth Centuries

\begin{tabular}{|c|c|c|c|c|c|c|}
\hline Country & Time period & universality & seats on company boards & $\begin{array}{l}\text { equity share- } \\
\text { holdings }\end{array}$ & $\begin{array}{l}\text { proxy voting } \\
\text { (a) }\end{array}$ & $\begin{array}{l}\text { extensive branch } \\
\text { networks (b) }\end{array}$ \\
\hline Argentina & esp. after 1890 & $\mathrm{Xd}$ & some & few & $?$ & $X$ \\
\hline \multirow[t]{2}{*}{ Australia } & before $1890 \mathrm{~s}$ & $\mathrm{X}$ & $?$ & some & $?$ & $X$ \\
\hline & $1895-1950 \mathrm{~s}$ & 0 & $?$ & few & $?$ & $X$ \\
\hline Austria-Hungary & pre-WWII & $\mathrm{X}$ & $X$ & $\mathrm{X}$ & $\mathrm{X}$ & $\mathrm{X}$ \\
\hline \multirow[t]{2}{*}{ Belgium } & $1830 s-1934$ & $\mathrm{Xd}$ & $?$ & $\mathrm{X}$ & $?$ & $X$ \\
\hline & $1934-1970 \mathrm{~s} \mathrm{e}$ & 0 & $?$ & 0 & $?$ & $X$ \\
\hline \multirow[t]{2}{*}{ Brazil } & $1850-1900$ & $\mathrm{Xd}$ & 0 & some & $?$ & $\mathrm{X}$ \\
\hline & post-1900 & $\mathrm{X}$ & some & 0 & 0 & $X$ \\
\hline \multirow[t]{2}{*}{ Canada } & $1900-13$ & $\mathrm{Xd}$ & some & some & $?$ & $X$ \\
\hline & esp. after WWI & 0 & some & few & $?$ & $\mathrm{X}$ \\
\hline Denmark & $1870-1913$ & $\mathrm{Xd}$ & some & some & $?$ & 0 \\
\hline England & esp. after $1850 \mathrm{~s}$ & 0 & few & few & $?$ & $X$ \\
\hline \multirow[t]{2}{*}{ Finland } & pre-WWI & 0 & some & few & $\mathrm{X}$ & $\mathrm{X}$ \\
\hline & $1920 s-1980 s$ & $\mathrm{X}$ & $\mathrm{X}$ & some & $\mathrm{X}$ & $\mathrm{X}$ \\
\hline \multirow[t]{3}{*}{ France } & $1800-1880$ & $\mathrm{X}$ & few & few & $?$ & 0 \\
\hline & $1880-1913$ & $\mathrm{Xd}$ & $\mathrm{X}$ & some & $\mathrm{X}$ & $\mathrm{X}$ \\
\hline & 1941-1984 & 0 & $?$ & & $?$ & $\mathrm{X}$ \\
\hline \multirow[t]{2}{*}{ Germany } & pre-1880 & $\mathrm{X}$ & few & few & $?$ & 0 \\
\hline & esp. after $1890 \mathrm{~s}$ & $\mathrm{X}$ & $\mathrm{X}$ & some & $X$ & $\mathrm{X}$ \\
\hline \multirow[t]{2}{*}{ Greece } & pre-WWI & $X d$ & some & some & $?$ & $X$ \\
\hline & $1928-1962$ & 0 & $\mathrm{X}$ & $\mathrm{X}$ & $?$ & $\mathrm{X}$ \\
\hline India & esp. after $1850 \mathrm{~s}$ & 0 & $?$ & few & $?$ & $\mathrm{X}$ \\
\hline Ireland & esp. after $1850 \mathrm{~s}$ & 0 & $?$ & few & $?$ & $\mathrm{X}$ \\
\hline \multirow[t]{2}{*}{ Italy } & 1890's-1920's & $\mathrm{X}$ & $\mathrm{X}$ & $\mathrm{X}$ & $?$ & $\mathrm{X}$ \\
\hline & 1930's-1980's & 0 & $?$ & 0 & $?$ & $\mathrm{X}$ \\
\hline \multirow[t]{2}{*}{ Japan } & pre-WWII & $\mathrm{Xh}$ & $?$ & & $?$ & $\mathrm{X}$ \\
\hline & post-WWII & 0 & $\mathrm{X}$ & $\mathrm{X}$ & $?$ & $\mathrm{X}$ \\
\hline Mexico & 1897-1913 & $0 \mathrm{~d}$ & some & some & $?$ & $\mathrm{X}$ \\
\hline Netherlands & 1860-1920s g & $\mathrm{Xd}$ & $\mathrm{X}$ & $\mathrm{X}$ & $?$ & $\mathrm{X}$ \\
\hline \multirow[t]{2}{*}{ New Zealand } & 1870-1895 & $\mathrm{Xd}$ & $?$ & some & $?$ & $\mathrm{X}$ \\
\hline & 1895- & 0 & $?$ & few & $?$ & $\mathrm{X}$ \\
\hline Norway & pre-WWII & 0 & 0 & 0 & $?$ & 0 \\
\hline \multirow[t]{2}{*}{ Portugal } & 1890s-WWII & $\mathrm{X}$ & $X$ & some & $?$ & few \\
\hline & post-WWII & $\mathrm{X}$ & $X$ & $\mathrm{X}$ & $?$ & $X$ \\
\hline Russia & 1890s-WWII & $\mathrm{X}$ & $X$ & $\mathrm{X}$ & $?$ & $\mathrm{X}$ \\
\hline Spain & esp. after 1890 s & $\mathrm{Xd}$ & $\mathrm{X}$ & $\mathrm{X}$ & $?$ & $\mathrm{X}$ \\
\hline Sweden & esp. after $1850 \mathrm{~s}$ & $\mathrm{Xd}$ & $\mathrm{X}$ & somef & some & $\mathrm{X}$ \\
\hline Switzerland & esp. post-1890s & $\mathrm{Xd}$ & $X$ & some & $?$ & $X$ \\
\hline \multirow[t]{3}{*}{ United States } & before 1914 & $\mathrm{X} \mathrm{i}$ & $\mathrm{X}$ & $\mathrm{X}$ & $?$ & 0 \\
\hline & 1914-1933 & $\mathrm{X}$ & some & few & $?$ & some \\
\hline & after 1933 & 0 & some & 0 & $?$ & some \\
\hline
\end{tabular}


Notes to Table 1:

a In many cases the extent of proxy voting by banks is difficult to measure accurately.

$\mathrm{b}$ In most cases, branching proceeded slowly until after the second half of the nineteenth century or even later. c Or since World War I.

d Some universal banks, some specialized. French universal banks moved more toward straight deposit banking after 1880 .

e After 1934, mixed banks were required to split into deposit banks and holding companies and the banks could not hold shares.

f Intentional acquisition of shares was illegal until 1909. Shareholdings could result from collateral held on bad loans.

g Some universal, some primarily commercial. Jonker claims that Dutch banks were universal only between 1910 and 1920. After about 1924, through WWII, the Dutch banks reverted to primarily commercial banking, with some low-risk company flotations.

$\mathrm{h}$ Japanese banks combined commercial and investment banking but were prohibited from acting as dealers in secondary markets.

i Bank structure varied considerably. Services were combined through commercial bank subsidiaries of investment banks. Compliance to (or interpretation of) the new laws also varied. 
Table 2. Persistence of Banking System Characteristics over the Twentieth Century

\begin{tabular}{|c|c|c|c|c|c|c|c|}
\hline Country & $\begin{array}{l}\text { universal } \\
\text { in 1913? 0-2 } \\
\text { (subjective) }\end{array}$ & $\begin{array}{l}\text { universal in } \\
\text { 1990s? 0-2 } \\
\text { (subjective } \\
\text { ratings) }\end{array}$ & $\begin{array}{l}\text { universal } \\
\text { in 1913? 0-1 } \\
\text { (subjective) }\end{array}$ & $\begin{array}{l}\text { universal in } \\
\text { 1990s? 0-1 } \\
\text { (subjective) }\end{array}$ & $\begin{array}{l}\text { bank-based in } \\
\text { 1990s? 1=yes } \\
\text { (based on } \\
\text { Levine, 2000) }\end{array}$ & $\begin{array}{l}\text { structure index } \\
\text { for 1990s } \\
\text { (Levine, 2000) }\end{array}$ & $\begin{array}{l}\text { size/activity of } \\
\text { equity markets in } \\
1913 \text { ? 0-2 } \\
\text { (subjective) }\end{array}$ \\
\hline Argentina & 1 & & 0 & & 1 & -0.18 & 1 \\
\hline Australia & 0 & & 0 & & 0 & 0.80 & 1 \\
\hline Austria-Hungary & 2 & 2 & 1 & 1 & 1 & -1.27 & 1 \\
\hline Belgium & 1 & 1 & 1 & 1 & 1 & -0.17 & 1 \\
\hline Brazil & 2 & & 1 & & 0 & 1.01 & 1 \\
\hline Canada & 1 & & 0 & & 0 & 0.82 & 1 \\
\hline Denmark & 1 & 2 & 1 & 1 & 0 & 0.17 & 1 \\
\hline England & 0 & 1 & 0 & 0 & 0 & 1.24 & 2 \\
\hline Finland & 1 & 1 & 1 & 1 & 1 & -0.76 & 0 \\
\hline France & 1 & 1 & 1 & 1 & 1 & -0.17 & 2 \\
\hline Germany & 2 & 2 & 1 & 1 & 0 & 0.17 & 2 \\
\hline Greece & 1 & 1 & 1 & 1 & 1 & -0.66 & \\
\hline India & 1 & & 0 & & 1 & 0.14 & 1 \\
\hline Ireland & 0 & 1 & 0 & 1 & 0 & 0.33 & \\
\hline Italy & 2 & 2 & 1 & 1 & 1 & -0.55 & 1 \\
\hline Japan & 1 & 0 & 1 & 0 & 0 & 0.86 & 1 \\
\hline Mexico & 1 & & 0 & & 0 & 0.90 & 1 \\
\hline Netherlands & 1 & 1 & 1 & 1 & 0 & 0.33 & 1 \\
\hline New Zealand & 0 & & 0 & & 0 & 0.49 & 0 \\
\hline Norway & 1 & 0 & 0 & 0 & 1 & -0.23 & 0 \\
\hline Portugal & 2 & 1 & 1 & 1 & 1 & -1.43 & 1 \\
\hline Russia & 2 & & 1 & & & & 1 \\
\hline Spain & 2 & 2 & 1 & 1 & 1 & -0.31 & 1 \\
\hline Sweden & 1 & 2 & 1 & 1 & 0 & 0.80 & 1 \\
\hline Switzerland & 1 & 2 & 1 & 1 & 0 & 1.58 & 1 \\
\hline United States & 1 & 0 & 0 & 0 & 0 & 1.34 & 2 \\
\hline
\end{tabular}

Sources: see appendix. 
Table 3. Economic Factors in Financial Development

\begin{tabular}{|c|c|c|c|c|c|c|c|c|c|c|c|c|c|}
\hline & \multicolumn{2}{|c|}{ FI/GNP (1880) } & \multicolumn{3}{|c|}{ FI/GNP growth (1880-1900) } & \multicolumn{2}{|c|}{ FI/GNP (1900) } & \multicolumn{3}{|c|}{ FI/GNP growth (1900-13) } & \multicolumn{3}{|c|}{ Market orientation, 1990's } \\
\hline $\begin{array}{l}\text { Real GDP per capita, } \\
1880\end{array}$ & $\begin{array}{l}0.06 \\
0.16\end{array}$ & & $\begin{array}{l}-0.001 \\
0.05\end{array}$ & & & $\begin{array}{l}0.10 \\
0.05\end{array}$ & & $\begin{array}{l}-0.0001 \\
0.02\end{array}$ & & & $\begin{array}{l}-0.00 \\
0.13\end{array}$ & & \\
\hline $\begin{array}{l}\text { Real GDP per capita - } \\
\text { squared, } 1880\end{array}$ & $\begin{array}{r}-0.01 \\
0.30\end{array}$ & & & & & $\begin{array}{l}-0.02 \\
0.09\end{array}$ & & & & & $\begin{array}{l}0.000 \\
0.09\end{array}$ & & \\
\hline $\begin{array}{l}\text { Industrial development, } \\
1880\end{array}$ & & $\begin{array}{l}0.05 \\
0.25\end{array}$ & & $\begin{array}{l}0.00 \\
0.44\end{array}$ & & & $\begin{array}{l}0.07 \\
0.12\end{array}$ & & & & & & \\
\hline $\begin{array}{l}\text { Industrial development - } \\
\text { squared, } 1880\end{array}$ & & $\begin{array}{l}0.00 \\
0.35\end{array}$ & & & & & $\begin{array}{l}0.00 \\
0.21\end{array}$ & & & & & & \\
\hline Real GDP per capita, 1900 & & & & & & & & & $\begin{array}{l}-0.001 \\
0.03\end{array}$ & & & $\begin{array}{l}-0.00 \\
0.11\end{array}$ & \\
\hline $\begin{array}{l}\text { Real GDP per capita - } \\
\text { squared, } 1900\end{array}$ & & & & & & & & & & & & $\begin{array}{l}2.41 \mathrm{e} \\
0.06\end{array}$ & \\
\hline $\begin{array}{l}\text { Real GDP per capita } \\
\text { annual average growth } \\
\text { rate, } 1880-1900\end{array}$ & & & & & $\begin{array}{l}-5.31 \\
0.79\end{array}$ & & & & & $\begin{array}{l}12.23 \\
0.04\end{array}$ & & & \\
\hline $\begin{array}{l}\text { Industrial/agricultural } \\
\text { employment, } 1913\end{array}$ & & & & & & & & & & & & & $\begin{array}{l}0.44 \\
0.04\end{array}$ \\
\hline Constant & $\begin{array}{c}-23.49 \\
0.60\end{array}$ & $\begin{array}{l}34.18 \\
0.14\end{array}$ & $\begin{array}{l}2.46 \\
0.01\end{array}$ & $\begin{array}{l}0.64 \\
0.00\end{array}$ & $\begin{array}{l}0.57 \\
0.05\end{array}$ & $\begin{array}{l}-25.87 \\
0.57\end{array}$ & $\begin{array}{l}52.52 \\
0.01\end{array}$ & $\begin{array}{l}0.51 \\
0.00\end{array}$ & $\begin{array}{l}0.60 \\
0.00\end{array}$ & $\begin{array}{l}0.06 \\
0.49\end{array}$ & $\begin{array}{l}1.15 \\
0.16\end{array}$ & $\begin{array}{l}1.08 \\
0.16\end{array}$ & $\begin{array}{c}-0.37 \\
0.15\end{array}$ \\
\hline Number of obs. & 14 & 14 & 14 & 14 & 14 & 18 & 19 & 19 & 20 & 20 & 22 & 24 & 17 \\
\hline $\mathrm{P}(\mathrm{F})$ & 0.08 & 0.46 & 0.05 & 0.44 & 0.79 & 0.06 & 0.22 & 0.02 & 0.02 & 0.04 & 0.16 & 0.07 & 0.04 \\
\hline
\end{tabular}

Note: All columns, except column three, use Huber/Bi-weight limited-influence estimation, for which no $\mathrm{R}^{2}$ statistics are reported. The adjusted $\mathrm{R}^{2}$ for column three is 0.23 . FI/GNP is the ratio of total assets of financial institutions to GNP, and the growth of that ratio is calculated as the difference in the ratio between the end and base years, divided by the ratio in the base year. GDP per capita annual average growth rate is calculated as the estimated coefficient of a time trend when the $\log$ of the ratio is regressed on that trend variable and a constant. The industrial development variable is the product of real GDP per capita and the ratio of industrial to agricultural employment. The final column includes European countries only. 
Table 4. Political Factors in Banking Structure

\begin{tabular}{|c|c|c|c|c|c|c|c|c|c|c|c|}
\hline \multirow[b]{2}{*}{ State centralization, 1880} & \multicolumn{3}{|c|}{ Two-choice indicator } & \multicolumn{3}{|c|}{ Three-choice indicator } & \multicolumn{3}{|c|}{ Equity-deposit ratio } & \multicolumn{2}{|c|}{ Market orientation } \\
\hline & $\begin{array}{l}2.54 \\
0.88\end{array}$ & $\begin{array}{r}-1.15 \\
0.93\end{array}$ & $\begin{array}{l}4.78 \\
0.70\end{array}$ & $\begin{array}{c}-11.06 \\
0.68\end{array}$ & $\begin{array}{r}-11.99 \\
0.67\end{array}$ & $\begin{array}{r}18.86 \\
0.42\end{array}$ & $\begin{array}{r}-23.95 \\
0.19\end{array}$ & $\begin{array}{r}-2.03 \\
0.89\end{array}$ & $\begin{array}{r}-9.05 \\
0.45\end{array}$ & $\begin{array}{r}-2.13 \\
0.02\end{array}$ & $\begin{array}{r}-4.06 \\
0.49\end{array}$ \\
\hline State centralization - squared & $\begin{array}{r}-0.15 \\
0.99\end{array}$ & $\begin{array}{l}2.19 \\
0.85\end{array}$ & $\begin{array}{r}-3.12 \\
0.76\end{array}$ & $\begin{array}{l}7.59 \\
0.74\end{array}$ & $\begin{array}{l}8.08 \\
0.71\end{array}$ & $\begin{array}{r}-17.72 \\
0.39\end{array}$ & $\begin{array}{r}21.41 \\
0.16\end{array}$ & $\begin{array}{l}3.93 \\
0.75\end{array}$ & $\begin{array}{l}8.99 \\
0.38\end{array}$ & & $\begin{array}{l}1.65 \\
0.74\end{array}$ \\
\hline GDP per capita, 1880 & $\begin{array}{l}-0.0005 \\
0.25\end{array}$ & & & $\begin{array}{l}-0.002 \\
0.04\end{array}$ & & & $\begin{array}{l}-0.000 \\
0.17\end{array}$ & & & & \\
\hline $\begin{array}{l}\text { GDP per capita growth, } 1880- \\
1900\end{array}$ & & $\begin{array}{r}84.22 \\
0.17\end{array}$ & & & $\begin{array}{r}236.26 \\
0.11\end{array}$ & & & $\begin{array}{r}-17.48 \\
0.77\end{array}$ & & & \\
\hline $\begin{array}{l}\text { Industry/agriculture } \\
\text { employment growth, } \\
\text { 1880-1913 }\end{array}$ & & & $\begin{array}{r}-0.68 \\
0.22\end{array}$ & & & $\begin{array}{r}-1.96 \\
0.11\end{array}$ & & & $\begin{array}{r}-0.70 \\
0.27\end{array}$ & & \\
\hline Constant & $\begin{array}{r}-0.16 \\
0.98\end{array}$ & $\begin{array}{r}-0.96 \\
0.81\end{array}$ & $\begin{array}{r}-0.87 \\
0.81\end{array}$ & $\begin{array}{r}10.87 \\
0.24\end{array}$ & $\begin{array}{l}3.05 \\
0.70\end{array}$ & $\begin{array}{r}-1.03 \\
0.86\end{array}$ & $\begin{array}{l}8.86 \\
0.17\end{array}$ & $\begin{array}{l}0.69 \\
0.85\end{array}$ & $\begin{array}{l}3.23 \\
0.37\end{array}$ & $\begin{array}{l}1.64 \\
0.01\end{array}$ & $\begin{array}{l}2.14 \\
0.20\end{array}$ \\
\hline Number of obs. & 17 & 18 & 18 & 17 & 18 & 18 & 14 & 15 & 15 & 18 & 18 \\
\hline $\mathrm{P}$ (chi-squared or F) & 0.21 & 0.29 & 0.37 & 0.07 & 0.18 & 0.25 & 0.27 & 0.54 & 0.34 & 0.02 & 0.07 \\
\hline Pseudo/adj. $\mathrm{R}^{2}$ & 0.19 & 0.15 & 0.13 & 0.39 & 0.25 & 0.21 & 0.11 & -0.06 & 0.05 & 0.24 & 0.20 \\
\hline
\end{tabular}

Note: P-values are entered below coefficient estimates. Two-choice models use probit regression, three-choice models use logit regression, and the equity-deposit models use OLS. State centralization is measured as the ratio of central to total government revenues. GDP per capita annual average growth rate is calculated as the estimated coefficient of a time trend when the log of the ratio is regressed on that trend variable and a constant. The industrial to agricultural employment growth is calculated similarly. Market orientation is the structure index given in Levine (2000). 
Table 5. Legal Tradition, Banking Structure, Financial Development, and Economic Growth

\begin{tabular}{|c|c|c|c|}
\hline & Common law & Civil law & Total/P(t-test) \\
\hline \multicolumn{4}{|l|}{ Cross tabulations: } \\
\hline Specialized banking & 7 & 3 & 10 \\
\hline Universal banking & 0 & 16 & 16 \\
\hline Specialized banking & 4 & 0 & 4 \\
\hline Partial universal banking & 3 & 12 & 15 \\
\hline Universal banking & 0 & 7 & 7 \\
\hline Total & 7 & 19 & 26 \\
\hline \multicolumn{4}{|l|}{ T-tests: } \\
\hline State centralization, 1880 & $0.58(6)$ & $0.69(12)$ & 0.15 \\
\hline Equity-deposit ratio, 1913 & $0.22(4)$ & $1.17(11)$ & 0.10 \\
\hline Market orientation, 1990's & $0.74(7)$ & $0.01(18)$ & 0.02 \\
\hline FI/GNP growth (1880-1900) & $0.57(5)$ & $0.96(10)$ & 0.30 \\
\hline FI/GNP growth (1900-1913) & $0.17(6)$ & $0.37(14)$ & 0.12 \\
\hline GDP per capita growth, $1820-1850$ & $0.011(5)$ & $0.005(12)$ & 0.03 \\
\hline GDP per capita growth, $1890-1900$ & $0.008(8)$ & $0.016(19)$ & 0.03 \\
\hline GDP per capita growth, 1900-1913 & $0.014(9)$ & $0.016(27)$ & 0.26 \\
\hline GDP per capita growth, $1950-1980$ & $0.024(12)$ & $0.035(29)$ & 0.01 \\
\hline GDP per capita growth, $1980-1992$ & $0.019(12)$ & $0.017(29)$ & 0.42 \\
\hline
\end{tabular}

Note: The third column reports total number of observations for the cross tabulations and significance ( $\mathrm{p}$-values of $\mathrm{t}$ statistics) for the t-tests. The t-tests are one-sided (testing that the larger mean is significantly larger), based on a 95 percent confidence interval. The number of observations used to calculate each mean is reported in parentheses. 